\title{
Analysis of market of various ‘Bt cotton' seed brand in Nanded district of Maharashtra
}

\section{K.P. KULKARNI, M.C. JADHAV, ZAINAB SHARIEF AND SEEMA}

Received : 04.04.2017; Revised : 05.09.2017; Accepted : 19.09.2017

\begin{abstract}
Study was conducted in Nanded district of Maharashtra, from study it was observed that dealer's recommendations and advice of the fellow farmers were ranked as the top most factors influencing farmer preferences. In case of Promotional activities field demonstration followed by farmers meeting, follow up visits by company representatives to the farmer's field, farmer's visit to research plots, live sample shown at dealers counter and campaigning was considered by the farmers as highly important category.

KEY WORDS : Farmer's preferences, Promotional measures, Bt cotton, Seed, Field demonstration, Dealer's recommendation

How to cite this paper : Kulkarni, K.P., Jadhav, M.C., Sharief, Zainab and Seema (2017). Analysis of market of various 'Bt cotton' seed brand in Nanded district of Maharashtra. Internat. J. Com. \& Bus. Manage, 10(2) : 193-197, DOI: 10.15740/HAS/IJCBM/10.2/193-197.
\end{abstract}

\section{MEMBERS OF THE RESEARCH FORUM}

Correspondence to:

K.P. KULKARNI, School of Agribusiness Management, College of Agriculture, Acharya N.G. Ranga Agricultural University, Rajendranagar, HYDERABAD (TELANGANA) INDIA

Email: krashna.pk@gmail.com

Authors' affiliations:

M.C. JADHAV, ZAINAB SHARIEF AND SEEMA, School of Agribusiness Management, College of Agriculture, Acharya N.G. Ranga Agricultural University, Rajendranagar, HYDERABAD (TELANGANA) INDIA 